\title{
PELATIHAN MANAJEMEN PERPUSTAKAAN UNTUK MENINGKATKAN MINAT BACA DI RPTRA DHARMA SUCI, PEJAGALAN, JAKARTA UTARA
}

\author{
Yustinus Yuniarto \\ Universitas Bunda Mulia \\ Email: yyuniarto@bundamulia.ac.id
}

\begin{abstract}
One of the main elements in the Tri Dharma Perguruan Tinggi is carrying out community service activities. Public Space Integrated Child Friendly (RPTRA) were built and developed by Jakarta Provincial Government has a library that needs to be managed properly. To increase interest in reading among library users, especially children, the Program Management Studies Bunda Mulia University, held a traning program in the library management and also held activities in order to increase interest in reading. The educational background or knowledge of the librarians of RPTRA who are not educated libraries of course make them limited in managing the library including developing activities related to the development of reading interest. Through the training of good library management to increase interest in reading is seen some things that can be felt directly by the librarians and the children as the majority of library users in RPTRA Dharma Suci. For the board perceived the benefits of knowledge about how to manage the library well. Then also gain knowledge on how to develop activities that can be used to develop reading interest among library users, especially children. For children as library users it is felt that through the example of storytelling activities, their interest in finding other stories through library collection books in RPTRA Dharma Suci can increase. This is certainly positive because it will make them spend more time in the library than playing on the streets. So therefore, the future of these children can continue to develop themselves in order to improve their welfare in the future.
\end{abstract}

Keywords: management, library, reading interest, welfare living

\begin{abstract}
ABSTRAK: Salah satu unsur utama dalam Tri Dharma Perguruan Tinggi adalah melaksanakan kegiatan pengabdian kepada masyarakat. Ruang Publik Terpadu Ramah Anak (RPTRA) yang dibangun dan dikembangkan oleh Pemprov DKI Jakarta memiliki perpustakaan yang perlu dikelola dengan baik. Untuk meningkatkan minat baca di kalangan pengguna perpustakan terutama anak-anak, maka Program Studi Manajemen Universitas Bunda Mulia mengadakan pelatihan manajemen perpustakaan guna memberikan pengetahuan bagi para petugas perpustakaan dalam mengelola perpustakaan dan juga mengadakan kegiatan dalam rangka meningkatkan minat baca. Latar belakang pendidikan atau pengetahuan para pengurus perpustakaan RPTRA yang bukan berpendidikan perpustakaan tentunya membuat mereka terbatas dalam mengelola perpustakaan termasuk mengembangkan kegiatan-kegiatan yang terkait dengan pengembangan minat baca. Metode yang digunakan adalah ceramah dan praktik langsung. Melalui pelatihan manajemen perpustakaan yang baik guna meningkatkan minat baca ini terlihat beberapa hal yang dapat dirasakan langsung oleh para pengurus perpustakaan dan juga anak-anak sebagai mayoritas pengguna perpustakaan di RPTRA Dharma Suci. Bagi para pengurus dirasakan manfaatnya yaitu pengetahuan mengenai bagaimana mengelola perpustakaan secara baik. Kemudian juga mendapatkan pengetahuan bagaimana mengembangkan kegiatan-kegiatan yang dapat digunakan untuk mengembangkan minat baca di kalangan pengguna perpustakaan terutama-anak-anak. Bagi para anakanak sebagai pengguna perpustakaan dirasakan bahwa melalui contoh kegiatan mendongeng, minat mereka untuk mencari cerita-cerita yang lain melalui buku-buku koleksi perpustakaan di RPTRA Dharma Suci dapat meningkat. Hal ini tentunya positif karena akan membuat mereka semakin banyak menghabiskan waktu di perpustakaan daripada bermain di jalanan. Sehingga dengan demikian, ke depannya anak-anak tersebut dapat terus mengembangkan diri demi meningkatkan kesejahteraan hidup mereka kelak.
\end{abstract}

Kata kunci: manajemen, perpustakaan, minat baca, kesejahteraan hidup 


\section{PENDAHULUAN}

\section{Latar belakang}

Salah satu unsur utama dalam Tri

Dharma Perguruan Tinggi adalah pelaksanaan Pengabdian Kepada Masyarakat atau Pemberdayaan Masyarakat. Kegiatan ini sangat penting dan berguna karena merupakan kewajiban bagi dosen dan mahasiswa untuk mengabdikan ilmunya kepada masyarakat sekitar yang membutuhkan. Selain itu, kegiatan ini juga merupakan bukti nyata penerapan ilmu yang diajarkan di kelas dalam kehidupan nyata. Sebagai tambahan, kegiatan pengabdian dan pemberdayaan ini juga merupakan bukti kepedulian institusi terhadap lingkungan sekitarnya.

Dalam beberapa tahun terakhir, Program Studi Manajemen Universitas Bunda Mulia aktif melakukan kegiatan pengabdian dan pemberdayaan masyarakat ini dalam berbagai bentuk dan kepada berbagai jenis tipe masyarakat. Salah satu kegiatan pengabdian kepada masyarakat tersebut diselenggarakan bekerja sama dengan RPTRA (Ruang Publik Terpadu Ramah Anak) Dharma Suci, Pejagalan, Jakarta Utara.

Ruang Publik Terpadu Ramah Anak (RPTRA) adalah sebuah program yang dicanangkan oleh Pemprov DKI Jakarta yang dalam pembangunannya menggunakan dana CSR (Corporate Social Responsibility) dari perusahaan-perusahaan. Jadi RPTRA tidak menggunakan dana APBD (Anggaran Pendapatan dan Belanja Daerah) DKI Jakarta.

Di setiap RPTRA yang dibangun oleh Pemprov DKI Jakarta terdapat Perpustakaan yang dibuka untuk umum dan dikelola oleh petugas yang memang pegawai atau staf RPTRA tersebut yang digaji oleh Pemprov. Oleh sebab itulah kami melihat perlunya pemberian materi mengenai manajemen perpustakaan yang baik dan juga meningkatkan minat baca bagi para pengunjung terutama anak-anak. Dengan wawasan yang diharapkan terus bertambah dengan terciptanya minat baca tersebut maka di harapkan juga kesejahteraan masyarakat akan meningkat.

\section{Identifikasi Masalah}

Sebagai pengurus perpustakaan di RPTRA tentunya pengetahuan dan kemampuan dasar dalam bidang perpustakaan adalah sebuah keharusan. Selain itu juga dibutuhkan pengetahuan dan kemampuan bagaimana melakukan dan mengembangkan kegiatan-kegiatan yang berkaitan dengan minat baca di kalangan pengguna perpustakaan.

Latar belakang pendidikan atau pengetahuan para pengurus perpustakaan RPTRA yang bukan berpendidikan perpustakaan tentunya membuat mereka terbatas dalam mengelola perpustakaan termasuk mengembangkan kegiatankegiatan yang terkait dengan pengembangan minat baca.

\section{Tujuan dan Manfaat Kegiatan}

Pada tanggal 01 Oktober 2016 Program Studi Manajemen Universitas Bunda Mulia melaksanakan pengabdian kepada masyarakat dengan bentuk pemberian pelatihan yang berguna untuk meningkatkan pengetahuan bagi para pengurus perpustakaan dan juga pengguna perpustakaan terutama anak-anak yang masih usia sekolah dasar di RPTRA Dharma Suci, Pejagalan, Jakarta Utara. Adapun yang menjadi target kegiatan ini adalah pengurus perpustakaan RPTRA dan siswa-siswi SD kurang lebih sebanyak 6 pengurus dan 25 siswa atau anak-anak. Dosen dan mahasiswa akan bertugas sebagai fasilitator atau pelatih di dalam kegiatan ini.

Manfaat dari kegiatan ini adalah para pengurus RPTRA dapat mengelola perpustakaan RPTRA dengan baik agar dapat meningkatkan minat baca anak-anak RPTRA karena berdasarkan data faktual, tata letak perpustakaan dan kegiatankegiatannya turut mempengaruhi minat baca anak-anak. Dan melalui budaya gemar membaca ini diharapkan pada kemudian hari dapat mengembangkan wawasan dan pengetahuan anak-anak dalam berkarya dan meningkatkan kesejahteraan hidup mereka kelak. 


\section{TINJAUAN PUSTAKA}

\section{Pengertian tentang Perpustakaan}

Sulistyo-Basuki (1991) memberikan batasan perpustakaan yaitu sebuah ruangan, bagian sebuah gedung, ataupun gedung itu sendiri yang digunakan untuk menyimpan buku dan terbitan lainnya yag biasanya disimpan menurut tata susunan tertentu untuk digunakan pembaca, bukan untuk dijual.

Webster's Third Edition International Dictionary edisi 1961 menyatakan bahwa perpustakaan merupakan kumpulan buku, manuskrip, dan bahan pustaka lainnya yang digunakan untuk keperluan studi atau bacaan, kenyamanan, atau kesenangan. Sedangkan organisasi seperti IFLA (International Federation of Library Associations and Institutions) memberikan definisi perpustakaan sebagai kumpulan materi tercetak dan media noncetak dan atau sumber informasi dalam computer yang disusun secara sistematis untuk digunakan pemakai (Sulistyo-Basuki, 1991).

Sulistyo-Basuki (1991) sendiri membagi beberapa tujuan kepustakawanan sebagai berikut:

1. Penyimpanan, artinya perpustakaan bertugas menyimpan buku yang diterimanya. Tujuan ini nyata sekali pada perpustakaan nasional yaitu perpustakaan yag ditunjuk oleh undangundang untuk menyimpan semua terbitan dari suatu Negara.

2. Penelitian, artinya perpustakaan bertugas menyediakan buku untuk keperluan penelitian.

3. Informasi, artinya perpustakaan menyediakan informasi yang diperlukan pemakai perpustakaan. Pemberian informasi ini dilakukan baik atas permintaan maupun tidak diminta. Dalam hal terakhir ini dilakan bila perpustakaan menganggap informasi yang tersedia sesuai dengan minat dan keperluan pemakai.

4. Pendidikan, artinya perpustakaan merupakan tempat belajar seumur hidup, terutama bagi mereka yang telah meninggalkan bangku sekolah.

5. Kultural, artinya perpustakaan menyimpan khazanah budaya bangsa atau masyarakat tempat perpustakaan berada serta juga meningkatkan nilai dan apresiasi budaya masyarakat sekitarnya melalui proses penyediaan bahan bacaan.

\section{Penyelenggaraan Perpustakaan}

Sjahrial-Pamuntjak (1986) memberikan beberapa syarat untuk menyelenggarakan perpustakaan yaitu perlu disediakannya tempat, tenaga, dan anggaran. Ketiga syarat ini adalah langkah pertama yang perlu dipikirkan sebelum dimulai dengan perpustakaan.

Tempat yang disediakan untuk perpustakaan harus terpisah dan aktifitas lain. Sekali-kali jangan membagi penggunaannya dengan ruang pengajar, ruang rapat, dan sebagainya. Harus mudah dicapai langsung, dan tidak melalui ruang kerja orang lain atau terletak pada tempat terpencil. Betapa kecilnya ruangan yang dapat tersedia, kenyamanan perlu dijaga, sehingga pengunjung merasa betah untuk berada di dalamnya.

Tenaga perpustakaan harus ada cukup waktu untuk melayani pengunjung, mempersiapkan koleksi dan menjalankan administrasi.

Anggaran tetap adalah syarat ketiga. Anggaran itu tidak hanya harus ada pada waktu perpustakaan didirikan untuk gedung, mebiler, peralatan dan koleksi perpustakaan, akan tetapi harus tersedia sesudah itu juga untuk perawatan, penggantian dan perkembangan selanjutnya, serta untuk gaji atau honor staf perpustakaan.

\section{Jenis Perpustakaan}

Sulistyo-Basuki (1991) membagi jenisjenis perpustakaan menjadi beberapa kelompok yaitu:

1. Perpustakaan internasional.

2. Perpustakaan nasional.

3. Perpustakaan umum dan perpustakaan keliling.

4. Perpustakaan swasta (pribadi).

5. Perpustakaan khusus.

6. Perpustakaan sekolah.

7. Perpustakaan perguruan tinggi

Perpustakaan internasional adalah perpustakaan yang didirikan oleh 2 negara atau lebih atau perpustakaan yang merupakan bagian sebuah organisasi 
internasional. Perpustakaan semacam ini baru muncul sekitar tahun-tahun pertama abad ke-20.

Perpustakaan nasional mempunyai fungsi utama yaitu menyimpan semua bahan pustaka yang tercetak dan terekam yang diterbitkan di suatu negara. Menurut ketentuan perundang-undangan, tugas Perpustakaan Nasional Indonesia adalah:

1. Melaksanakan pengumpulan, pengolahan, dan pendayagunaan bahan pustaka yang diterbitkan di Indonesia sebagai koleksi deposit nasional.

2. Melaksanakan pengumpulan, pengolahan, pengembangan, serta pendayagunaan bahan pustaka dengan mengutamakan bidang ilmu-ilmu sosial dan kemanusiaan terbitan asing.

3. Melaksanakan penyusunan dan penerbitan bibliografi nasional.

4. Melaksanakan tugas sebagai pusat kerjasama antar perpustakaan di dalam negeri maupun dengan luar negeri.

5. Memberikan jasa referensi studi, jasa bibliografi, dan informasi ilmiah.

6. Melaksanakan urusan tata usaha Perpustakaan Nasional.

Perpustakaan umum adalah perpustakaan yang diselenggarakan oleh dana umum dengan tujuan melayani umum. Ciri perpustakaan umum adalah sebagai berikut:

a. Terbuka untuk umum artinya terbuka bagi siapa saja tanpa memandang perbedaan jenis kelamin, agama, kepercayaan, ras, usia, pandangan politik, dan pekerjaan.

b. Dibiayai oleh dana umum. Dana umum ialah dana yang berasal dari masyarakat.

Biasanya dikumpulkan melalui pajak dan dikelola oleh pemerintah. Dana ini kemudian digunakan untuk mengelola perpustakaan umum. Karena dana berasal dari umum maka perpustakaan umum harus terbuka untuk umum.

c. Jasa yang diberikan pada hakekatnya bersifat Cuma-Cuma. Jasa yang diberikan mencakup jasa referal artinya jasa memberikan informasi, peminjaman, konsultasi studi sedangkan keanggotaan bersifat Cuma-Cuma di Indonesia masih ada yang memungut biaya untuk menjadi anggota, namun hal ini semata-mata karena alasan administratif belaka, bukanlah prinsip utama.

Yang termasuk kelompok perpustakaan umum adalah:

a. Perpustakaan wilayah.

b. Perpustakaan provinsi.

c. Perpustakaan umum kotamadya.

d. Perpustakaan umum kabupaten.

e. Perpustakaan umum kecamatan.

f. Perustakaan umum desa.

g. Perpustakaan umum untuk anggota masyarakat yang memerlukan media khusus, misalnya perpustakaan untuk tuna netra.

h. Perpustakaan umum untuk anggota masyarakat yang memerlukan bacaaan khusus karena faktor usia.

i. Perpustakaan keliling yaiatu bagian perpustakaan umum yang mendatangi pemakai dengan menggunakan kendaraan.

Perpustakaan swasta atau perpustakaan pribadi artinya perpustakaan yang dikelola pihak swasta atau pribadi dengan tujuan melayani keperluan bahan pustaka bagi kelompok, keluarga, atau individu tertentu.

Perpustakaan khusus dapat merupakan perpustakaan sebuah departemen, lembaga Negara, lembaga penelitian, organisasi massa, militer, industri, maupun perusahaan swasta.

Perpustakaan sekolah adalah perpustakaan yang tergabung pada sebuah sekolah, dikelola sepenuhnya oleh sekolah yang bersangkutan, dengan tujuan utama membantu sekolah untuk mencapai tujuan khusus sekolah dan tujuan pendidikan pada umumnya.

Perpustakaan perguruan tinggi adalah perpustakaan yang terdapat pada perguruan tinggi, badan bawahannya, maupun lembaga yang berafiliasi dengan perguruan tinggi, dengan tujuan utama membantu perguruan tinggi mencapai tujuannya. Tujuan perguruan tinggi di Indonesia dikenal dengan nama Tri Dharma perguruan tinggi (pendidikan, penelitian, dan pengabdian masyarakat) maka perpustakaan perguruan tinggi pun bertujuan membantu melaksanakan ketiga darma perguruan tinggi. 
Merujuk pada keterangan di atas, maka dapat disimpulkan bahwa perpustakaan di RPTRA adalah perpustakaan umum.

\section{METODE}

Untuk mengajak para petugas perpustakaan RPTRA Dharma Suci, Pejagalan, mengerti tentang dasar pengelolaan sebuah perpustakaan maka dilakukan dengan cara ceramah dan praktek. Pelatihan dilakukan selama satu hari.

\section{Ceramah.}

Para petugas perpustakaan diberikan dasar-dasar pengetahuan mulai dari pengadaan bahan pustaka, pengolahan, dan sirkulasi. Materi-materi yang diberikan adalah sebagai berikut:

a. Pengetahuan mengenai apa itu perpustakaan. Sejarah singkat, tugas, dan fungsi perpustakaan secara umumnya.

b. Jenis-jenis koleksi perpustakaan: buku dan non buku.

c. Langkah-langkah pengolahan buku: pembuatan buku induk, pembuatan kartu buku, pembuatan kantong buku, kartu lembar kembali, pemberian cap dan label, dan juga penyampulan buku.

d. Pengklasifikasian koleksi dengan menggunakan system DDC (Dewey Decimal Classification).

e. Pengenalan perabot dan peralatan di perpustakaan.

f. Promosi kegiatan perpustakaan seperti mendongeng, lomba menulis resensi, lomba puisi, dan sebagainya.

\section{Praktek.}

Praktek-praktek yang dilakukan adalah sebagai berikut:

1. Melakuan pencatatan di buku induk dan kemudian memasukkannya juga kepada database di computer.

2. Melakukan klasifikasi dengan sistem DDC secara dasar.

3. Melihat contoh dari pelatih dan mencoba untuk berdongeng di depan anak-anak pengguna perpustakaan RPTRA guna meningkatkan minat baca di kalangan pengguna perpustakaan terutama anak-anak.

\section{HASIL DAN PEMBAHASAN}

Kegiatan Pengabdian

Kepada

Masyarakat RPTRA Dharma Suci berjalan dengan baik. Terlihat dari antusias para Pengurus Perpustakaan RPTRA beserta anak-anak peserta yang tekun mengikuti selama acara berlangsung.

Pada Pengurus Perpustakaan diberikan pengetahuan tentang Manajemen Perpustakaan mulai dari pengadaan, pengolahan dan sirkulasi simpan dan pinjam buku. Mereka merasa sangat terbantu dengan pengetahuan bagaimana menata buku dengan baik di rak buku.

Hal ini dibuktikan dari hasil Hasil Umpan

Balik Pelaksanaan dari para pengurus RPTRA pada tabel 1.

Peserta anak-anak juga sangat antusias dan gembira mengikuti selama acara berlangsung. Mereka banyak berperan aktif ketika para pendamping dari dosen dan mahasiswa memberikan games edukatif dan bercerita / berdongeng tentang kisah yang diambilkan dari sebuah buku. Penyampaian tentang pentingnya menambah pengetahuan lewat membaca dapat diterima dengan baik oleh anak-anak peserta. 
Tabel 1. Hasil Umpan Balik

\begin{tabular}{lc}
\hline MATERI DAN IMPELEMENTASI & Mean \\
\hline 1.Manfaat materi bagi peserta & 3,40 \\
\hline 2.Relevansi materi atau sarana yang digunakan oleh narasumber & 3,40 \\
\hline 3.Ketepatan media atau sarana yang digunakan oleh narasumber & 3,40 \\
\hline 4. Proses atau kegiatan pelaksanaan & 3,60 \\
\hline 5.Penambahan pengetahuan/keterampilan yang dapat diaplikasikan & 3,60 \\
\hline
\end{tabular}

\begin{tabular}{ll}
\hline INSTRUKTUR/NARASUMBER & \\
\hline 1.Kemampuan atau penguasaan terhadap materi & 3,60 \\
\hline 2.Kemampuan dalam menyampaikan materi & 3,60 \\
\hline 3.Kemampuan menggunakan metode yang tepat dengan materi & 3,20 \\
\hline 4.Kemampuan dalam menjawab pertanyaan peserta & 3,40 \\
\hline 5.Kemampuan menciptakan suasana yang mendukung kegiatan & 3,20 \\
\hline
\end{tabular}

\section{Sumber: data diolah penulis, 2017}

\section{SIMPULAN DAN SARAN}

Melalui pelatihan manajemen perpustakaan yang baik guna meningkatkan minat baca ini terlihat beberapa hal yang dapat dirasakan langsung oleh para pengurus perpustakaan dan juga anak-anak sebagai mayoritas pengguna perpustakaan di RPTRA Dharma Suci.

a. Bagi para pengurus dirasakan manfaatnya yaitu pengetahuan mengenai bagaimana mengelola perpustakaan secara baik. Kemudian juga mendapatkan pengetahuan bagaimana mengembangkan kegiatankegiatan yang dapat digunakan untuk mengembangkan minat baca di kalangan pengguna perpustakaan terutama-anakanak.

b. Bagi para anak-anak sebagai pengguna perpustakaan dirasakan bahwa melalui contoh kegiatan mendongeng, minat mereka untuk mencari cerita-cerita yang lain melalui buku-buku koleksi perpustakaan di RPTRA Dharma Suci dapat meningkat. Hal ini tentunya positif karena akan membuat mereka semakin banyak menghabiskan waktu di perpustakaan daripada bermain di jalanan.

\section{DAFTAR PUSTAKA}

Rimbarawa, Kosam. 2007. Dasar-dasar doku mentasi, seri: buku pelajaran ilmu perpustakaan No.5. Hakaeser, Jakarta.

Sjahrial-Pamuntjak, Rusina.1986. Pedoman penyelenggaraan perpustakaan. Djambatan, Jakarta.

Sulistyo-Basuki. 1993. Pengantar ilmu perpustakaan. Gramedia Pustaka Utama, Jakarta.

Priyono, Sugeng Agus. 2006. Perpustakaan atraktif. Grasindo, Jakarta. 